\title{
The evolution of the United States Climate Change Policies and missed leadership opportunities*
}

\author{
La evolución de las políticas climáticas de \\ Estados Unidos y las oportunidades de \\ liderazgo perdidas
}

\author{
María del Pilar Bueno Rubial**
}

\begin{abstract}
The main objective of this work lies in exposing the evolution and the main features of the US climate policies expressed in its national, subnational, and foreign dimensions that are naturally interwoven. Thus, we assert some of the main features of traditional political approach to climate change include: an emphasis on costs and the impact of measures to address climate change in the American economy and its economic growth; the questioning of climate science as insufficient to justify the costs of the action; the questioning of the differentiation between developed and developing countries as a valid argument for the US to take the lead in international climate action; the resistance to assume mitigation commitments that collide with the principle
\end{abstract}

\footnotetext{
* Este artículo fue realizado en el contexto de una estancia de investigación en el Georgetown Climate Center, apoyada por el Consejo Nacional de Investigaciones Científicas y Tecnológicas de Argentina y la Comisión Fulbright.

** Doctora en Relaciones Internacionales, Facultad de Ciencia Política y Relaciones Internacionales, Universidad Nacional de Rosario (UNR); Magíster en Sistemas Ambientales Humanos, Centro de Estudios Interdisciplinarios (CEI), Universidad Nacional de Rosario (UNR); Especialista en Sistemas de Gestión de Calidad en Medio Ambiente, Centro de Estudios en Relaciones Internacionales de Rosario (CERIR); Bachiller Comercial y Licenciada en Relaciones Internacionales, Universidad Nacional de Rosario (UNR). Investigadora del Consejo Nacional de Investigaciones Científicas y Técnicas de la Argentina (CONICET). Profesora en varias universidades como la Universidad Nacional de Rosario, la Universidad Nacional de Entre Ríos y la Universidad Nacional de La Plata. mbueno@conicet.gov.ar, pilarbuenorubial@gmail.com. ORCID https://orcid.org/0000-0003-3408-6271. Recibido: 17 de julio de 2020. Modificaciones: 23 de septiembre de 2020. Aceptado: 25 de septiembre de 2020.
} 
of national sovereignty and fundamental freedoms inherited from the founding fathers and the related tension between the role of States and free market value.

We also recognize that political ideology and partisanship continue to play a key role in climate change polices in the US. While political and economic denialism has not been able to immobilize subnational governmental and non-governmental climate initiatives, it has undermined the opportunity and the responsibility of the US to sustain leadership as international projection.

This contribution follows a qualitative approach based on the analysis of climate change policies at different scales. It is based mainly on documentary and qualitative data analysis.

Keywords: United States - Climate Change - Climate Policies Leadership.

\section{RESUMEN}

El principal objetivo de este trabajo radica en exponer la evolución y las principales características de las políticas climáticas estadounidenses expresadas en sus dimensiones nacional, subnacional y exterior, que se entrelazan naturalmente. Por lo tanto, afirmamos que algunas de las principales características del enfoque político tradicional al cambio climático incluyen: un énfasis en los costos y en el impacto de las medidas para abordar el cambio climático en la economía estadounidense y su crecimiento económico; el cuestionamiento de la ciencia del clima como insuficiente para justificar los costos de la acción; el cuestionamiento de la diferenciación entre países desarrollados y en vías de desarrollo, como argumento válido para que Estados Unidos tome la delantera en la acción climática internacional; la resistencia a asumir compromisos de mitigación que chocan con el principio de soberanía nacional y las libertades fundamentales heredadas de los padres fundadores, y la tensión relacionada entre el rol de los Estados y el valor de libre mercado.

También reconocemos que la ideología política y el partidismo continúan desempeñando un papel clave en las políticas de cambio climático en Estados Unidos. Si bien el negacionismo político y económico del cambio climático no ha podido inmovilizar las iniciativas gubernamentales y no gubernamentales subnaciona- 
les, ha socavado la oportunidad y la responsabilidad de Estados Unidos de sostener el liderazgo y su proyección internacional.

Esta contribución mantiene un enfoque cualitativo basado en el análisis de las políticas de cambio climático a diferentes escalas. Se basa principalmente en el análisis de datos documentales y cualitativos.

Palabras Clave: Estados Unidos - Cambio Climático - Políticas Climáticas - Liderazgo.

\section{INTRODUCTION}

The United States climate change policies are one of the most controversial and interdisciplinary topics of our times. At the same time, climate change is not only one of the most important international topics and challenges, but also an interdisciplinary theme that recalls the roots of IR nourished by different social studies and sciences.

Climate change has been approached by IR scholars from very diverse perspectives, including regime theory (Rosendal, 2001; Young, 2004; Yamin and Depledge, 2004; Oberthür and Tänzler, 2007), the regimen complex (Keohane and Victor, 2011), multilevel, polycentric and complex governance (Betsill and Bulkeley,2006; Ostrom, 2010; Abbott, 2012) and constructivism (Ungar, 1992; Stehr and Storch, 1995; Rosa and Dietz, 1998; Demeritt, 2001; Oels, 2005; Pettenger, 2007; Schroeder, 2008; Hermann and Mahlko, 2012).

At the same time, it is remarkable the literature regarding the relationship of the national-international dimensions of public policies. Early in the academy, Katzenstein (1976) pointed out that the content of the foreign policies results as much from the constraints of domestic structures as from international effects. As Oberthür and Tänzler (2007: 257) affirmed applied to climate change policies: "international institutions and domestic policies can thus be conceptualized as feeding back on each other over time".

Additionally, it is worth highlighting the literature on climate change leadership, including the role of the United States (Peterson, 2004; Parker et.al,2012; Parker, Karlsson and Hjerpe, 2015; Parker and Karlsson, 2018).

There are several studies focused on particular issue-topics that appear in US approach to climate change. Lee, Arroyo and Roy (2001) referred to themes re-emerging throughout the 20th century and playing an important role by shaping US policy. Cass (2007) 
affirmed that the climate debate in the US was bogged down in the science and the economics of climate change. We agree that the recurrence to these two domains is evident in statements, paper positions and submissions of the federal government at least from Ronald Reagan to Donald Trump administration. At the same time, our work is based on the idea that the initial framing of the problem (i.e. how the debate was born and developed in a country) is conclusive to understand its behavior, as well as policy and norms construction (Pettenger, 2007). Consequently, Ronald Reagan framing encompassed key features such as a long-term issue, scientific uncertainty and unjustified costs for American interest and economy, as well as the faith in technology as the final solution of any problem.

The contribution and main objective of this work lies in exposing the evolution and the main features of the US climate policies expressed in its domestic (national and subnational) and foreign dimensions that are naturally interwoven. Thus, we assert some of the main features of traditional political approach to climate change include: an emphasis on costs and the impact of measures to address climate change in the American economy and its economic growth; the questioning of climate science as insufficient to justify the costs of the action; the questioning of the differentiation between developed and developing countries as a valid argument for the US to take the lead in international climate action; the resistance to assume mitigation commitments that collide with the principle of national sovereignty and fundamental freedoms inherited from the founding fathers and the related tension between the role of States and free market value.

We also recognize that political ideology and partisanship continue to play a key role in climate change polices in the US. While political and economic denialism has not been able to immobilize subnational governmental and non-governmental climate initiatives, it has undermined the opportunity and the responsibility of the US to sustain leadership as international projection.

This contribution followed a qualitative approach based on the analysis of climate change policies at different scales. It used as primary sources of research, reports of International Organizations, as well as official documents of the government of US and the States. As secondary sources, it visited literature on climate change, US climate policies and other areas consistent with the objective. As regards the techniques of data analysis, the contribution is based mainly on documentary and qualitative data analysis.

While it is possible to trace the antecedents of the United States' climate policy in previous years, we concentrated on the period that extends from the 1980s to the present, since it coincides with the beginning of international negotiations on climate 
change. This timeframe is reflected on the first part of the contribution, while the second one is focused on the last 20 years of social changes towards climate change. Thus, it is organized in two sections. The first one is focused on US climate policies from 1980s to our days trying to interlink national and international positions. The second one portrays the relationship between the features of traditional US approach to climate policy and changes occurred in the last 20 years at different levels.

\section{i. United States Federal Administration and Climate Change Policies}

The climate related norms in the US were sanctioned from the fifties, associated to the pollutant's discussion and its effects in air quality, including the Air Pollution Control Act, the Clean Air Act and the Air Quality Act. This topic was an important entry point to generate rules regarding climate change, especially in relation to the legal battle on EPA competence on climate change (Ferreira et. al, 2012).

However, the federal interest on climate change as a result of international and national increasing awareness began under President Ronald Reagan (1981-1989), even when decisions did not take place in light of the diagnosis of high economic costs and insufficient science evidence. It should be underlined that Reagan embraced the Montreal Protocol that seek to phase out ozone depleting substances in light of a cost-benefit analysis (save money).

The challenges increased significantly under the Presidency of George H.W. Bush (1989-1993) comprising in the international scenario, the organization of the Noordwyk Conference on Global Climate Change. In this Conference, the majority of developed countries agreed on stabilizing emissions by 2020, in contrast with the US reluctance to targets. The US argued that the emission reduction targets were too rigid and did not consider properly different national circumstances. National circumstances language has been part of US's interest for a long time and it is not casual the addition made to the principle of common but differentiated responsibilities (CBDR) by the US and China in the Joint Declaration of November 2014 and that appears in the PA. Also, in Noordwyk, the US position was to continue with scientific research and developing national strategies and programs with domestic monitoring and verification (Bodansky, 2001; Depledge, 2005) in a more conservative approach to international commitments.

In addition, when negotiating the United Nations Framework Convention on Climate Change (unfCcc) in Rio de Janeiro, the US delegation had specific instructions related to the 
establishment of institutions and the implementation mechanisms. Along with the OECD countries, the US supported launching strong institutions, including a scientific advisory body, a committee for implementation and detailed reporting systems. Thus, the original position of the US involved the construction of an international climate architecture that would promote research and allow the country to have a leading role. But this leadership was not interpreted in terms of greater international commitments to reduce emissions, but rather to safeguard their freedoms, while modeling the conditions and characteristics of that architecture.

At the same time, at the national level, the unleashed scandals linked to the area of budgets and the alteration of data and testimonies on climate change and its effects are facts to mention. Another key episode was the meeting of the IPCC held in the US, which led the President to recognize that human actions were generating an impact on the atmosphere and to propose that market mechanisms should occupy a key role in the solution (Cass, 2007). Hence, Bush administration was critical in terms of the introduction of the market mechanisms, the public recognition of climate science facts and the negotiation and signing of the UNFCCC.

William J. Clinton (1993-2001) experienced critical moments while in office, such as the negotiation of the
Berlin Mandate and the adoption of the Kyoto Protocol, at the international arena. This administration ratified the importance of the flexibility mechanism as a way to achieve domestic consensus around the proposal. At the same time, it accepted the target of reducing 7 per cent of emissions below 1990 for the period 2008-2012. However, the pressure coming from business and industry lobbies was very strong to reject the target since they considered developing countries should not be excluded (Bodansky, 2001; Depledge, 2005).

Moreover, this Presidency had to deal with the results of the midterm elections that changed the scenario with a Republican Congress. However, all these internal pressures did not cause the rejection of the drafts of the Berlin Mandate including the differentiation between developed and developing countries. On the contrary, the US submitted its own proposal of document that agreed with differentiation and not commitments for developing countries while including the flexible mechanisms (UNFCCC,1997). At the same time, it could be mentioned that the US Clinton administration advocated for the inclusion of the six main greenhouse gases and the concept of multi-year targets that it was finally turned into the idea of different periods of commitments with similar consequences and a set of suggestions of institutions and mechanisms for 
implementation and compliance (Farber and Carlarne, 2018).

The national context had deep consequences in terms of the plan to tax energy consumption, the Climate Action Plan and the international position towards the Kyoto Protocol considering the Byrd-Hagel Resolution in 1998. This set back could help to understand the decision of the Clinton administration to avoid submitting the KP to the Congress even when it continued to have international active participation at the UNFCCC.

Thus, the Democrats favored reaching the first UNFCCC implementation document (KP), committing to reduce US emissions. However, it was an unambitious deal, which included the interests of the United States in its own interpretation of leadership. While Clinton's national and international climate policy did not reflect a break in the social climate culture, but the gradual advance and social polarization around the identified values.

The new Republican administration in charge, with George W. Bush (2001-2009) leading the White House, not only withdrew from the KP but also announced the Protocol was dead. The domestic critics as well as international ones increased. Situation that forced Bush Jr. to create the National Energy Policy Development Group headed by vice president Cheney and the increasing introduction of energy issues in the presidential statements including the State of the Union of 2002.
However, the approach was based on energy and not climate change.

The main arguments exhibited by the Bush administration for the withdrawal were the incomplete state of knowledge in reference to climate science. Secondly, that the US could not be part of an international environmental agreement that potentially could harm its economy and, finally, the absence of commitments of developing countries. It was also mentioned the lack of flexibility of targets, mirroring the Byrd-Hagel Resolution. The announcement was made, first, by the head of EPA, Christine Whitman, and then by President Bush. Even some of the most important critic voices with the KP disagreed with the pathway of isolation that the administration chose instead of assuming a proactive approach. This was interpreted in many ways including a manifestation of US unilateralism (Kahn, 2003).

As stated by Depledge (2005), even though the US expected everything collapse when Bush announced the withdrawal, the international community did not accept one state to demolish the multilateral process. The most important signal was given in occasion of the Marrakesh Accords and Bonn Agreements where both developed and developing countries showed good will to reaffirm the regime. And the US did not block those accords and agreements. That means, the US did not agree to accomplish the KP but did not prevent others to 
do it. Actions that have a lot of similarities with the process lead by President Trump.

With respect to the international critics and questioning, Bush experienced a setback regarding his decision to request the National Academy of Sciences to review the results of the IPCC report, AR3, since the decision was to support what was said by the Panel. In turn, facing the criticism of the isolation of the US in the UNFCCC after the withdrawal, Bush tried to advance in bilateral initiatives that did not lead to major changes nor had the intended impact.

Also, in response to the national and international criticism to presidential decisions, in 2002, after the conclusion of the Marrakesh Accords, the US submitted a new proposal to the UNFCCC comprising a domestic target for a reduction in the GHG intensity of the US economy of 18 per cent by 2012. This encompassed voluntary initiatives, as well as a voluntary system of monitoring and reviewing. The document was composed by the National Climate Change Technology Initiative, the Climate Change Research Initiative, and associated international cooperation (Depledge, 2005). This could be interpreted as a way to give a response to the critics as well as to the argument of the incomplete state of knowledge (Waterman, 2003).

Even being enthusiastic, it is necessary to recognize that the Convention entered in a difficult process where the $\mathrm{KP}$ was internationally maintained mainly by the European efforts that saw in the Protocol a good opportunity. For that reason, there were many questions and antipathies about the role of the US at Bali negotiations. It was a dilemma to bring it back to the negotiations table while avoiding a less ambition approach. The price was a weaken Bali Road Map where the US negotiators achieved to remove critical parts of the draft related to global emissions reductions. The setbacks comprised a mention to the global emission peak in the next 15 years, a collective aggregated target for developed countries and reductions near to 25 to 40 per cent below 1990 levels by 2020. In addition, it reintroduced the discussion on developing countries binding reductions that gave the idea of trying to blow up the negotiations (Christoff, 2008). Despite the obstructionist role played by Bush administration in Bali, the conference reached the Roadmap towards Copenhagen where climate architecture change materialized in the Us-BASIC agreement.

In Copenhagen one of the most important changes identified was the reorientation of the negotiations to the emissions of developing countries, in particular of China (Bodansky, 2010). Consequently, the emergence of BASIC coalition integrated by China, India, Brazil and South Africa was a novelty in the unfCCC arena. Instead of assuming a defensive position, the countries agreed to develop institutional arrangements and voluntary emission reduction targets, supposing a 
new leadership in climate action but respecting the principle of $\mathrm{CBDR}$ as well as equity (Hochstetler, 2012).

Furthermore, this Conference was the first signal of the alliance between China and the United States that shaped the negotiations towards Paris with significant bilateral milestones in 2014 and 2015.

It should be recognized that no candidate before Barack Obama (20092016) had based much of his presidential campaign on a topic like climate change. This could be linked to the issue of the domestic salience explained by Cass (2007). Obama's campaign was focused on reducing emissions with an energy transition to renewables and a just transition of labor forces. The campaign included the promise to reduce oil dependency and confront climate change at the same time reducing 80 per cent of emissions by 2050 , improving the share of renewables and developing carbon trading system. Ideas that where integrated in the Green Economy Recovery Programme (Pollin et. al,2008). This does not prejudge that the US position had changed in terms of its traditional resistance to assume international commitments to reduce emissions. However, in Copenhagen the US announced the pledge to reduce its emissions 17 per cent over 2005 levels by 2020 . And going into detail, it is possible to see that the design of Paris entails different interpretations about the bindingness of national determined contributions (NDCS). Condition that has been extensively discussed in the US as a consequence of PA avoiding the Congress and having been approved by executive decision of the President.

As with President Clinton, the Obama administration encountered impediments in the domestic sphere and especially in the Congress, where the 2009 American Clean Energy and Security Act did not pass the Senate. This act was important not only because of the reduction of emissions pursued - concurrent with the Copenhagen announcements- but also because it encompassed the EPA competence in regulating GHG emissions. Nonetheless, it should be pointed out that as a result of 2007 Massachusetts v. EPA Supreme Court decision, the EPA is required to regulate GHG.

Even with a strong domestic resistance, during second period, Obama advanced more decisively in terms of the Climate Action Plan (CAP) and the Clean Power Plan (CPP). Both concentrated in reducing emissions of power industries and transportation, improving the renewables and progressing in emissions reductions. The first one, established by Executive Presidential Order in 2013, covered the increase of efficiency in appliances, federal buildings and other sectors; double energy productivity by 2030 compared to 2010 levels; reduce methane emissions from oil land and gas production by 40 to 45 per cent below 2005 levels by 2025 and double electricity generation from solar, wind and geothermal sources by 2020 . 
The Clean Power Plan (CPP), proposed in 2014 and announced formally in 2015, introduced emissions reduction from power sector of 32 per cent below 2005 levels by 2030, setting targets for each States but providing some space for them to decide how to accomplish. Nevertheless, the Supreme Court applied a stay to the CPP in February 2016 in response to different applications of States and industry groups.

From 2009 to 2015, the US was as explicit as possible in terms of the progress made in relation to its auto-proclaimed climate leadership at the multilateral process. Thus, it exhibited power and transportation regulation, results in the renewable energy production, the Clean Action Plan and the Clean Power Plan of 2015 that pledge to reduced emissions by 32\% from 2005 levels by 2030 (US, 2013; EPA, 2015).

Additional to the strategies at both the multilateral and the national level, bilateral negotiations played a big role, in particular with China. For that reason, the US-China Memorandum of Understanding to enhance cooperation on Climate Change of 2009, as well as the Joint Announcement of November 2014 and the Joint Presidential Statement of September 2015 were significant milestones for the multilateral negotiations. The first one, set the basis for the Copenhagen Accord, the second one agreed the mitigation targets of both countries that were included in their intended nationally determined contributions (INDC), and the language for CBDR adding "in light of different national circumstances" (article 2 of the PA). The last one, comprised other issues such as adaptation, finance, domestic steps to achieve the mitigation pledge and bilateral and multilateral efforts.

US bounded leadership in the UNFccc context had its hottest moments in Copenhagen and Paris as revealed by the surveys distributed between negotiators, researchers and NGOs attendants to COP from Poznan in 2008 to Paris in 2015. US leadership was recognized by $19 \%$ of the participants in 2008 in comparison with $48 \%$ of Cancun (2010). The percentages were reduced during next meetings but climbed again in Lima and Paris (Karlsson et. al., 2012; Parker and Karlsson, 2018).

Finally, the administration headed by Donald Trump (2017-2020) also included climate change in its presidential campaign. Nevertheless, the campaign was against the Paris Agreement and the candidate promised the withdrawal. The withdrawal took place in June of 2017 through a presidential speech charged with criticism to the Agreement, the Green Climate Fund, the differentiated burdens between developed and developing countries, with special emphasis on China and its impact on the distribution of the American welfare. Trump referred to the renegotiation of the Agreement as well as its non-mandatory character. This message obtained a quick 
response of leaders, not only of different countries but also of NGOs, private actor, academia, religions and other sectors, confirming the serious consequences of this decision.

The rollback of the Trump administration on climate change extends not only to the international level and its effects on the Paris Agreement implementation, including climate finance and mitigation, but also on the domestic level. Climate denial has reached significant extremes including the rejection of the National Climate Assessment in 2018. Although the report concludes that climate change will be devastating for the American economy costing 500 billion per year by the end of the century, the administration has refuted its validity.

In addition, the backsliding involves undoing the rules on carbon dioxide emission reductions from power plants and efficiency standards for vehicles and appliances. The withdraw of the CAP, the repeal process of the CPP, the new leases for oil drilling and the Executive Order on energy independence are just some of the news from 2017 to 2020.

According to the Climate Deregulation Tracker of Columbia University, there is a data base full of information on Trump's administration rollback measures. Some of the most important from 2017 to 2020 are:

- All kind of relaxing measures of environmental rules during COVID-19 in 2020.
- $\quad$ EPA and NHTSA finalized in March 2020 a rule rolling back motor vehicle greenhouse gas emissions and corporate fuel economy standards.

- EPA issued guidance revising definitions in the Clean Air Act, in November 2019.

- EPA took action to revoke California's authority to set its own vehicle emissions standards that are more climate-protective than federal requirements, in September 2019.

- $\quad$ EPA issued the Affordable Clean Energy (ACE) Rule, repealing the Clean Power Plan with less stringent emission standards for existing power plants, in June 2019.

- EPA proposed to increase the $\mathrm{CO}_{2}$ emission standard for new coalfired power plants in December 2018.

- EPA and NHTSA proposed to weaken the greenhouse gas emission and fuel economy standards for light-duty vehicles, in August 2018.

- Trump issued an Executive Order allowing the use of coastal, ocean, and Great Lakes resources for energy production, in June 2018.

- EPA announced no enforcement of a 2015 rule prohibiting the use of HFCs with high GWP as substitutes for ozone-depleting substances, in April 2018.

- $\quad$ EPA decided not to proceed with the development of methane 
emission guidelines for existing oil and gas sources in June 2017.

- $\quad$ Trump signed an Executive Order on Implementing an America-First Offshore Energy Strategy for expanding offshore drilling, in April 2017. EPA withdrew two proposed rules to supplement the Clean Power Plan final rule: federal plans and model rules for implementing the GHG emission guidelines for existing power plants, and a rule with details of the Clean Energy Incentive Program (CEIP), in March 2017.

- Trump issued an Executive Order directing EPA to review and potentially rescind or re-write Clean Power Plan, CO2 emission standards for new power plants, and methane emission standards for the oil and gas sector. It also revoked Executive Orders and actions such as: guidance on calculating the social costs of GHG emissions, an imposing a moratorium on federal coal leasing, and guidance on accounting climate change in environmental reviews, in March 2017.

The federal government led by President Trump has spearheaded a pullback on climate issues domestically and internationally. However, and as supported in the second section, the federal government it is every time more isolated in its climate denial in light of state and non-state actors climate actions and perceptions.

\section{Changes and trendS in the Features of US TRAditional POLITICAL APPROACH TO CLIMATE CHANGE}

It could be said that federal climate policies and their international projection were accompanied by a social,economic and political evolution of the topic on the United States in dialogue with the features identified. Thus, we start by analyzing some data vis-à-vis the changes experienced in the United States over the last 20 years in terms of emissions, production and energy consumption, energy efficiency and participation of renewable energies in the energy bill, among others.
According to EPA (2018), the US has achieved the decouple of its emissions from its economic growth. Also, it reached the peaking in its emissions in 2007 or 2008 depending on the source (Climate Data Explorer CAIT; UNEP, 2018; BP, 2018). The last inventory of GHG emissions indicates that the US released 6511.3 ммт of $\mathrm{CO}_{2} \mathrm{e}$ in 2016, showing an increase of 2.4 per cent from 1990. However, this country is well-known for using 2005 as base year since the increase in emissions from 1990 to 2005 were of 12 per cent 
approximately. At the same time, the report recognized that emissions from 2015 to 2016 decrease in 1.9\%.

The US emissions, in terms of GHGS composition, continued to be mainly concentrated on carbon dioxide which represented in 2016, 81.6 per cent of the total amount of emissions. The emissions of $\mathrm{CO}_{2}$ from 1990 to 2005 increased 20 per cent. These two ideas help us to understand why the US chose 2005 as base year and why it pushed a lot for all the gases inclusion in the UNFCCC and not only the $\mathrm{CO}_{2}$.

At the same time, the composition by sector is highly concentrated in energy using IPCC guidelines. This sector represented 84 per cent of total US emissions both in 1990 and 2016 and 86 per cent in 2005. The second sector is agriculture with a participation of 7 to 8 per cent of total US emissions in 1990 and 2016. The third sector is industrial processes ( 5 per cent) and the last one is the waste sector.

Since transportation and electric power represents a big part of fossil fuels combustion in the US, it is interesting to analyze the composition of electric power generation during the same period and it helps to understand the changes experienced in the last decade. The composition of electric power generation is based on coal, natural gas, renewable energies, nuclear energy and petroleum. While nuclear generation maintained its position of 20 per cent during 1990 to
2016, the contribution of petroleum decreased and the role of renewables almost duplicated from 10 to 19 per cent. At the same time, natural gas triplicated from 10 to 30 per cent and that gain represents the transition from coal to natural gas in the US since coal decreased the same percentage (60 to 30 per cent).

The transition between coal and natural gas is related to the boom in hydraulic fracturing turning US to a natural gas producer and replacing in part coal, as well as reducing emissions. This transition was a big part of the US pledge in Copenhagen (reduce 17 per cent of its emissions below 2005 levels by 2020), as well as its extension to the NDC (reduce emissions by 26 to 28 per cent below 2005 levels by 2025) submitted in 2015.

Analyzing the primary energy consumption by source in 2016, petroleum occupied the first place with almost 37 per cent, followed by natural gas (29.1 per cent), coal (14.8 per cent), renewables (10.5 per cent) and nuclear electric power (8.6 per cent).

As reported by EIA, the domestic primary energy production reached 90\% of primary energy consumption in 2017 with a difference covered by crude oil imports. At the same time, petroleum, natural gas and coal, all fossil fuels, accounted for three thirds of the national primary production (US EIA, 2020).

Coal peaked in 2008 and the decline in its production is due to its 
substitution for natural gas in electricity generation. However, crude oil production was highest in record in 2019. This is also accompanied by other records in the same year in natural gas production, nuclear energy production as well as renewable energy production and consumption, driven by solar and wind energy.

The United States is the main producer of crude oil globally (2019) and in recent years, the measures taken by the government favored reaching records in the production of hydrocarbons. Although the country's global role in leading the energy transition that was a key aspect of achieving the Paris Agreement is obscured by these aspects, renewable energies have continued to have a substantial and growing role.

Other information we consider interesting for this study is equity dimension of emissions and fair share. According to the World Resources Institute, the cumulative emissions of the US from 1850 to 2012 put it in the first place of the table (366421.27 $\mathrm{Mt} \mathrm{CO}_{2} \mathrm{e}$ ) followed by the $\mathrm{EU}$ (the 28 states, 329071,78 $\mathrm{MtCO}_{2} \mathrm{e}$ ) and China $\left(150108.52 \mathrm{MtCO}_{2} \mathrm{e}\right)$. At the same time, the cumulative emissions per capita has the US in second place after Luxemburg and it is interesting to notice that China is after 100 position and under the average of the World). From 1990 to 2014, the US released 17.65 per cent of cumulative total GHG emissions.
Also, the Climate Action Tracker (САт) analyzed the pledges under the NDC as well as the later events related to the withdrawal. CAT catalogued US NDC of 2015 as insufficient since it is inconsistence with Paris Agreement purpose of limiting the increase in global temperature to $20 \mathrm{C}$ and make efforts to achieve 1.5 oC. With US pledge and according to the carbon budget, the temperature would increase 2 to $3 \mathrm{\varrho C}$. But the effort is highly insufficient with current circumstances, driving the world to a 3 to 4 oC increase in global temperature. The idea of insufficiency of the NDC is also based on the historical emissions.

The US could catalogue its own NDC as sufficient based on cost-effectiveness and reductions costs by GDP (Climate Action Tracker 2018). This is key when comparing the interpretations of CBDR and differentiation made by developing countries, and in particular China and India with the US. Cost-effectiveness of emission reduction and capability to pay has been cornerstones of US positions at the UnFCCC.

Research conducted by Kuramochi and others (2017), as well as ratified by the American Initiative Pledge, evidenced that the US will accomplish a half of its NDC pledge with non-federal climate initiatives with its current activities. However, with additional strategies and actions proposed, it could achieve two thirds of the NDC and even more 
with additional measures (Bloomberg Philanthropies, 2018).

The US economy is still based on the burning of fossil fuels, although the progress in renewable energy is undeniable. At the same time, the transition to natural gas in the US exhibits the traditional cost-benefit analysis additional to the climate change assumptions.

Thus, the first feature identified related to the high costs and the deep impact of the post carbon transition for the US economy is gradually questioned.

It is also irrefutable that renewable energies made great progress, improving the power capacity, reducing costs and increasing the investments and technology related. The US was the second investor in renewable power and fuels in 2018 (not including hydropower over $50 \mathrm{MW}$ ), after China, and the first annual investor in biodiesel production and ethanol. In addition, it was the second investor in solar and wind power capacity and third in geothermal (REN21, 2019).

Considering renewable electricity generation by State, according to the Georgetown Climate Center Data (excluding hydroelectric power and biomass) in 2015 , Iowa had $37 \%$ of its electricity generated by renewable sources, followed by South Dakota (32.3\%), Kansas (29.7\%), Oklahoma (25.5\%) and California (25.3\%).

Renewable energy production and portfolio should be also understood in light of the ranking of the top five state GHG emitters in the US, led by Texas (13 per cent of total US emissions in 2014), followed by California (6.7 per cent of total US emissions in 2014), Pennsylvania, Illinois and Ohio (these three States release between 4 and 5 per cent of total US emissions in 2014 each) (wri CAIT Climate Data Explorer).

California, the second emitter in the US, is an interesting case to understand the potential for clean energy production and consumption while at the same time, it continued to lead crude oil production in 2015 (1,214 billion megajoules). It was followed by Texas (7,621.63 billion megajoules), and preceded by North Dakota (2,590.32 billion megajoules). California also set a renewable energy standard of 33 per cent by 2020. Its fuel use by 2015 is composed half by petroleum, 34.25 per cent by Natural Gas, 12.3 per cent by renewables and 2.78 per cent by nuclear energy with almost none participation of coal. Meanwhile, in Texas, the first emitter of the US, the distribution of fuel use is similar with a half of petroleum and more than 30 per cent in Natural Gas. But the difference is that coal participation is bigger in Texas with 10.34 per cent.

With respect to the sources of electricity produced in 2016, both profiles of California and Texas are different, since the renewables in California took the second place (42.3 per cent) after Natural Gas (47.2 per cent) while, in Texas, the participation of renewables 
is lower (13.6 per cent) and coal had a fourth of the total.

California renewable profile and portfolio are based on the work of different actors. It includes State administrations that believed in the energy transition as a profitable business, contradicting the social value on the damages that this kind of change could involve for the American economy. In that way, governor Jerry Brown was one of the most important voices in the "We are still in" movement as well as in the American Pledge Initiative.

California is not the only American State with a renewable portfolio. Oregon set a renewable energy standard of 25 per cent by 2025 for large utilities and 5 to 10 per cent for smaller ones; Colorado also set a 30 per cent, as well as Connecticut and Minnesota settled 27 per cent by 2020 and 2025, respectively (GCC Data). This data, together with the fact that US private investment in renewable energy could reach $\$ 1$ trillion between 2018 and 2030 (Marcacci and Kenkins, 2018), depict changes in American social climate values.

However, and at the same time, the federal government's rollback not only has deep effects outside but also inside the US, including in its air quality. The State of the Air (2018) by the American Lung Association provided evidence that the US must continue to fight against climate change and enforce the Clean Air Act. The report displayed that many cities experienced more days when smog reached unhealthy levels, while some of these cities reduced their burden of year-round particle pollution.

The US has a long tradition of questioning climate science, in particular associated to the Republican Party. This tradition includes IPCC reports. The historical reactions have comprised the complete denial of the findings, as well as the pressure on the national academies of sciences to accompany the questioning. Nevertheless, the US National Academy of Sciences (NAS) has confirmed some of the most salient outcomes of the IPCC reports. The report "Climate Change: evidence and causes" explains the relation between increasing concentrations of GHG emissions and global warming, where human activities such as burning of fossil fuels since the Industrial evolution are one of the main drivers. It also recognized the increase in the $\mathrm{CO}_{2}$ concentration, in particular since 1970, as well as the increase in the global average surface temperature.

The Nas is not the only scientific body in the US which has published results aligned with the IPCC findings. The American Meteorological Society, the American Geophysical Union and the American Association for the Advancement of Science are other organizations validating the causes and effects of climate change (Oreskes, 2004).

This information is also consistent with the National Climate Assessment in its fourth edition of 2018 that 
affirmed climate change creates new risks and exacerbates existing vulnerabilities in communities across United States, challenging human health and safety, quality of life, economic growth, infrastructure and property.

As affirmed by Depledge (2005), climate science questioning is contrasting with the long tradition of the US in the exercise of leadership in scientific research. This leadership had its expression in sponsoring activities of early climate research, as well as the establishment of the IPCC. The US was also one of the major contributors to the first two IPCC reports.

A key piece of information is the role of public opinion and how the denial discourse with an economistic and supposedly scientific root permeates -or notAmerican society.

Surveys conducted by the Pew Research Center (2019) evidenced that the number of Americans who consider environmental laws and regulations are worth the cost has increase from 59 to 63 per cent while the ones who say it costs too many jobs and hurts the economy had decreased from 37 to 30 per cent from 2017 to 2019. This movement is also accompanied by a more positive approach of republicans whose approval increase from 36 to 45 per cent.

In another survey conducted by Pew, between March and April 2018, 18 per cent of conservative republicans recognized earth warming is caused by human activities, while 39 per cent of moderate or libertarians had the same perception. At the time, 69 moderate to conservative democrats and 83 per cent of libertarian democrats coincide with the same assertion.

Even though, the Republicans' reluctance is still tangible in polls, social climate change is also happening among its followers. A survey conducted in 2018 by Pew Research Group showed that $59 \%$ of Americans said climate change was currently affecting their local communities. The recognition of the political ideology is critical but even more important could be to understand how their own experiences and ways of life shape their perceptions towards climate change. 67 per cent of the participants who live within 25 miles of coastlines said climate change was affecting their communities regardless their political ideology.

Another survey conducted between May and June 2016 by Pew about many dimensions of the politics of climate change in American society, showed that 36 per cent of Americans are personally concerned about climate issues where 3 fourths were democrats. The block on climate science displayed 67 per cent believed the scientist should have a major role in policy decision. However, the republicans where astonishingly critic when referring to the capacity of scientists to understand the causes and provide solutions to climate change. This coincided with a very low trust in climate scientists coming from the republicans. 
These results in the various surveys of recent years could be interpreted as the progress of social change in America regarding climate change, its causes and consequences, much more when it comes to its effects in communities. However, political ideology remains a key factor in explaining why climate denial still exists as a social value although in decline.

In any case, given the features of climate policy identified in this contribution, it seems that the first two -the economic aspects and the questioning of science-are the most resisted at the social level by various actors, starting with the States.

Furthermore, even if there is no political movement that promotes a radically different NDC from the one submitted in 2015 that alters the burdens in a new interpretation of differentiated responsibilities, its fulfillment is sought as a business model and leadership projection.

The reluctance of the US to assume the international climate leadership in terms of targets is a constant that did not formally change with the Obama administration. This feature may be linked to the deep articulation between the principle of defense of national sovereignty and other principles of the founding fathers that have sustained the US looking inside. This looking inside is also interwoven with the debate between the role assigned to the state and market-freedoms. As expressed by Lee, Arroyo and Roy (2001), the US culture is generally averse to government intervention, what helps to explain its attitude towards mitigation commitments. However, a survey conducted by Benenson Strategy Group for Union of Concerned Scientist and Sierra Club in January 2015, in the context of the Paris Agreement negotiation, revealed that 72 per cent of Americans supported the US signing an international climate change agreement. Besides, 65 per cent said the US should take the lead and make meaningful reductions in its carbon emissions and other gases that may cause global warming (Sheppard, 2015). So that, American people do not reject international agreements in climate change as well as US action in this territory. Nevertheless, these social perceptions are also linked to political ideology.

Collomb (2014) studied the ideology of climate change denial in the US. He affirmed that global warming possessed a philosophical challenge to libertarians and conservatives based on the idea that government power should avoid damaging individual freedoms. But, at the same time, climate change created a challenge of global proportions that could only be averted with a long term and generalized governmental action. Thus, the actions to face this challenge could enter into conflict with free market principles.

Historical discussion on developed countries taking the lead in climate change fight, always found in the US an important resistance. The social perception that placing the burden 
in developed countries of reducing emissions could affect American competitiveness and welfare was not the only base of Byrd-Hagel resolution and current federal policy. Also, the feeling that Chinese interests will be beneficiated in a context of a particular interpretation of fairness that could be identified in many American documents and interventions including Trump's announce of withdrawal of the PA.

Probably because UnFCCC architecture is built upon a different way to interpret the fairness and the historical responsibilities, the US has had problems to fit.

\section{Conclusion}

There are certain features that characterize the evolution of the American approach to climate change policy. But these features worked and were applied in different ways from the eighties to today and they have been gradually but not unanimously nor uniformly questioned by governmental and nongovernmental actors.

Despite the fact that to this day there are political positions that are deniers of climate change and its effects, the first two characteristics have been the most questioned by different actors and sectors with strong consequences both at national and international arena. The information available regarding the falsity of the argument about the negative impact of climate action on the well-being of Americans is becoming more conclusive. Contrary to that, the post-carbon economy and the just transition cannot be delayed if the US pursue to sustain an economic advantage globally.

Additionally, scientific organizations and alliances in the country have been abandoning the fear of supporting global climate science and in particular the IPCC findings.

However, it is difficult to identify national voices with international projection that radically modify the critical stance towards the strict differentiation between developed and developing countries. Thus, those seeking to sustain the US international climate effort have shown that it is possible to comply with the NDC submitted in 2015 but not necessarily they went further in the sense of ambition and mitigation commitments.

There is an intrinsic relationship between social changes towards climate change and public policies at all levels. As affirmed by Fogel (2007), the social diffusion of international climate change policy and norms grew steadily in the US from the 2000s, where the leadership exercised by diverse actors is remarkable and has sustained the climate effort even when federal policy acted backwards. That is why, climate change norms had reached great salience, including GHG emission 
reduction targets, use of renewable energies and energy efficiency.

The changes identified in US public opinion do not contradict the position assumed by this country at the international level either by one or the other government. To the extent that foreign policy is understood as an international projection, this projection responds to different interests of economic and political groups.

The linkage between interests behind fossil fuels and climate change denial is evident as well as its advocacy in the US government at different levels, including its impact on public opinion. It should be recognized that climate denial is not exclusively a position of the Republican Party because many republicans have taken a more favorable position towards climatic change. Nonetheless, the ideological bias of one and the other party is clear.

Climate leadership has a negative relationship with the delay in abandoning the main features of the traditional US approach to climate policy. Insofar as the United States, instead of leading the post-carbon economy and favoring research and climate science -as diagnosis and engine of solutions-, slows them down, it leaves open leadership opportunities in favor of other countries. And what is more condemnable, it does not fulfill its international responsibility.

\section{REFERENCES}

Abbott, K. (2012). "The transnational regime complex for climate change”, Environment and Planning C: Government and Policy, vol. 30, no 4, pp. 571-590.

American Lung Association (2018). The State of the Air 2018. Recuperado el 5 de junio de 2020 de https://www.lung. org/assets/documents/healthy-air/stateof-the-air/sota-2018-full.pdf

Betsill, M.y Bulkeley, H. (2006), “Cities and the multilevel governance of global climate change", Global governance: A review of multilateralism and international organizations, vol. 12, no 2, pp. 141-160.

Bloomberg Philanthropies (2018). Fulfilling America's Pledge: How States, Cities, and Businesses Are Leading the United States to a Low-Carbon Future. Recuperado el 5 de junio de 2020 de https:// www.bbhub.io/dotorg/sites/28/2018/09/ Fulfilling-Americas-Pledge-2018.pdf Bodansky, D. (2010). “The Copenhagen climate change conference: a postmortem”, American Journal of International Law, vol. 104, no 2, pp. 230-240.

Bodansky, D. (2001). "The history of the global climate change regime”, International relations and global climate change, vol. 23, no 23, p. 505.

British Petroleum. (2018). BP Energy Outlook 2018 edition. Recuperado el 5 de junio de 2020 de https:/www.bp.com/ content/dam/bp-country/de_ch/PDF/ 
Energy-Outlook-2018-edition-Booklet. pdf

Bureau of Public Affairs (2009). Memorandum of Understanding on Enhancing Cooperation on Climate Change, Energy and the Environment at the U.S.-China Strategic and Economic.

Dialogue, Washington DC (July 28, 2009). Recuperado el 13 de febrero de 2020 de https://2009-2017.state.gov/r/pa/prs/ ps/2009/july/126597.htm

Cass, L. (2007). "Measuring the Domestic Salience of International Environmental Norms: Climate Change Norms in American, German and British Climate", en Pettenger, Mary, Social construction of Climate Change. Power, Knowledge, Norms and Discourses, New York: Routledge, pp. 47-74.

Christoff, P. (2008). "The Bali roadmap: Climate change, COP 13 and beyond", Environmental Politics, vol. 17, no 3, pp. 466-472.

Climate Action Tracker (2018). USA. Recuperado el 5 de junio de 2020 de https:// climateactiontracker.org/media/documents/2018/4/CAT_2017-11-06_CountryAssessment_USA_8fXxIrP.pdf

Collomb, J.D. (2014). "The ideology of climate change denial in the United States" [version electrónica], European journal of American studies, vol. 9, no 1.Recuperado el 20 de junio de 2020 de https:// doi.org/10.4000/ejas.10305

Columbia University, Climate Deregulation Tracker. Recuperado el 12 de junio de 2020 de https://climate.law.columbia. edu/climate-deregulation-tracker

Demeritt, D. (2001). "The Construction of Global Warming and the Politics of Science", Annals of the Association of American Geographers, vol. 91, № 2, pp. 307-337.

Depledge, J. (2005).'Against the grain: The United States and the global climate change regime', Global Change, Peace \& Security, vol.17, no 1, pp. 11-27.

Environmental Protection Agency (2018). Inventory of GHG Emissions and Sinks 1990-2016. Recuperado el 5 de junio de 2020 de https://www.epa.gov/sites/production/files/2018-01/documents/2018_ executive_summary.pdf

Environmental Protection Agency (2015). Clean Power Plan Fact Sheet. Recuperado el 5 de junio de 2020 de https://archive. epa.gov/epa/cleanpowerplan/fact-sheetoverview-clean-power-plan.html

Farber, D. y Cinnamon C. (2018), "Climate Change Law”, Minnesota: Foundation Press.

Ferreira, S.; Ferreira, K. y Vigevani, T. (2012). "An overview of domestic aspects in US climate policy”, Revista Brasileira de Política Internacional, vol.55, pp. 88-103. Hochstetler, K. (2012). “The G-77, BASIC, and global climate governance: a new era in multilateral environmental negotiations", Revista Brasileira de Política Internacional, vol 55, pp. 53-69.

IPCC (2018). Global Warming of $1.5^{\circ} \mathrm{C}$. Recuperado el 5 de junio de 2020 de https://www.ipcc.ch/sr15/

Kahn, G. (2003). "The Fate of the Kyoto Protocol under the Bush Administration”, Berkeley J. Int'l Law, vol.21, p. 548. Karlsson, Ch.; Hjerpe, M.; Parker, Ch. y Linnér, B. (2012). “The Legitimacy of Leadership in International Climate 
Change Negotiations”, Ambio, vol. 41, № 1, pp. 46-55.

Katzenstein, P. (1976). “International relations and domestic structures: Foreign economic policies of advanced industrial states", International Organization, vol. 30, no 1, pp. 1-45.

Keohane, R.y Victor, D. (2011). The regime complex for climate change. Perspectives on politics, vol. 9, pp. 7-23.

Kuramochi, T.; Höhne, N.; Sterl, S.; Lütkehermöller, K. y Seguers, J-C. (2017). States, cities and businesses leading the way: a first look at decentralized climate commitments in the US, New Climate Institute, September 2017. Recuperado el 5 de junio de 2020 de https://newclimate.org/wp-content/uploads/2017/09/ states-cities-and-regions-leading-theway.pdf

Lee, H.; Arroyo, V.y Roy, M. (2001). “US Domestic Climate Change Policy”, Climate Policy, vol. 1, no 3, pp. 381-395.

Marcacci, S. y Jenkins, G. (2018). “Top Renewable Energy Financiers Reveal Pathway To \$1 Trillion In U.S. Investment”, Forbes, July 11. Recuperado el 5 de junio de 2020 de https://www.forbes. com/sites/energyinnovation/2018/07/11/ top-renewable-energy-financiers-reveal-pathway-to-1-trillion-in-u-s-investment/\#2c96a3a534b0

Oberthür, S. y Tänzler, D. (2007). "Climate policy in the EU: international regimes and policy diffusion”, en Harris, Paul (ed.), Europe and global climate change: Politics, foreign policy and regional cooperation, Cheltenham: Edward Elgar Publishing, pp. 255-278.
Oels, A. (2005). "Rendering Climate Change Governable: From Biopower to Advanced Liberal Government?", Journal of Environmental Policy \& Planning, vol. 7, no 3, pp. 185-207.

Oreskes, Naomi (2004), “The scientific consensus on climate change", Science, vol. 306, no 5702, pp.1686-1686.

Ostrom, E. (2010). "Polycentric systems for coping with collective action and global environmental change", Global environmental change, vol. 20, no 4, pp. 550-557.

Parker, Ch. y Karlsson, Ch. (2018). "The UN climate change negotiations and the role of the United States: assessing American leadership from Copenhagen to Paris", Environmental Politics, vol.27, no 3, pp. 519-540.

Parker, Ch.; Karlsson, Ch. y Hjerpe, M. (2015), "Climate change leaders and followers: Leadership recognition and selection in the UNFCCC negotiations", International Relations, vol. 29, no 4, pp. 434-454.

Parker, Ch.; Karlsson, Ch.; Hjerpe, M. y Linnér, B. (2012). "Fragmented climate change leadership: making sense of the ambiguous outcome of COP-15", Environmental Politics, vol. 21, no 2, pp. 268-286.

Pettenger, M. (2007). Social construction of Climate Change. Power, Knowledge, Norms and Discourses, New York: Routledge.

Petterson, T. (2004). "The evolution of state climate change policy in the United States: Lessons learned and new directions”, Widener LJ, vol. 14, pp. 81-120.

Pew Research Center (2019). 'More Republicans say stricter environmental 
regulations are 'worth the cost,' February 2019, available at http://www.pewresearch. org/fact-tank/2019/02/07/more-republicans-say-stricter-environmental-regulations-are-worth-the-cost/ (5 June, 2020).

Pew Research Center (2018). Democrats and Republicans tend to disagree over evidence of and main causes of climate change. Recuperado el 5 de junio de 2020 de http://www.pewinternet.org/2018/05/14/ majorities-see-government-efforts-to-protect-the-environment-as-insufficient/ ps-05-10-18_report-10/

Pew Research Center (2018). Most Americans say climate change affects their local community, including two-thirds living near coast', May 2018. Recuperado el 5 de junio de 2020 de http://www. pewresearch.org/fact-tank/2018/05/16/ most-americans-say-climate-changeaffects-their-local-community-including-two-thirds-living-near-coast/

Pollin, R.; Garrett-Peltier; H.; Heintz, J.; Scharber, H. (2008). Green recovery: A program to create good jobs \& start building a low-carbon economy, Political Economy Research Institute, University of Massachusetts at Amherst.

Renewable Energy Policy Network for the $21^{\text {st }}$ Century (2019). Renewables 2019. Global Status Report.Recuperado el 5 de junio de 2020 de https://y3i6c3u4.rocketcdn.me/wp-content/uploads/2019/05/ gsr_2019_full_report_en.pdf

Rosa,E. y Dietz, T. (1998)."Climate change and society: Speculation, construction and scientific investigation", International Sociology, vol. 13, o 4, pp. 421-455.

Rosendal, K. (2001). "Overlapping international regimes: the case of the
Intergovernmental Forum on Forests (IFF) between climate change and biodiversity", International Environmental Agreements, vol. 1, № 4, pp. 447-468.

Schroeder, M. (2008). "The construction of China's climate politics: transnational NGOs and the spiral model of international relations", Cambridge Review of International Affairs, vol. 21, no4, pp. 505-525.

Sheppard, K. (2015). Poll Finds Strong Majority Of Americans Support An International Climate Agreement, The Huffington Post. Recuperado el 5 de junio de 2020 de https:// www.huffingtonpost.com/2015/03/30/ us-climate-agreement_n_6972434. html?utm_hp_ref=green\&ir=Green

Stehr, N. y Von Storch, H. (1995), "The social construct of climate and climate change, Climate Research, vol. 5, o 2, pp. 99-105.

The White House (2015). U.S.-China Joint Presidential Statement on Climate Change, September 25, 2015. Recuperado el 5 de junio de 2020 de https://obamawhitehouse.archives. gov/the-press-office/2015/09/25/us-china-joint-presidential-statement-climate-change

The White House (2014). U.S.-China Joint Announcement on Climate Change, November 11, 2014. Recuperado el 5 de junio de 2020 de https://obamawhitehouse.archives.gov/the-press-office/2014/11/11/us-china-joint-announcement-climate-change

United Nations Environmental Program (2018). Emissions Gap Report 2018. Recuperado el 5 de junio de 2020 de 
https://www.unenvironment.org/ interactive/emissions-gap-report/

United Nations Framework Convention on Climate Change (1997). Ad Hoc Group on the Berlin Mandate. Implementation of the Berlin Mandate. Recuperado el 5 de junio de 2020 de http:// unfccc.int/cop3/resource/docs/1997/ agbm/misc01a4.htm

United States (2013). Clean Action Plan. Recuperado el 5 de junio de 2020 de https:/obamawhitehouse.archives.gov/ sites/default/files/image/president27sclimateactionplan.pdf

United States Academy of Sciences and Royal Society (2014). Climate change: evidence and causes. Recuperado el 5 de junio de 2020 de http://dels.nas.edu/ resources/static-assets/exec-office-other/ climate-change-full.pdf

United States Energy Information Administration (2016). Visual data provided by the Georgetown Climate Center. Recuperado el 5 de junio de 2020 de http:// www.georgetownclimate.org/SEAtool United States Global Change Research Program (2018). Impacts, Risks and Adaptation in the United States: Fourth National Climate Assessment', Washington, DC: U.S. Global Change Research Program.

United States Energy Information Administration (2020). US Energy facts explained. Recuperado el 10 de junio de 2020 de https:/www.eia.gov/ energyexplained/us-energy-facts/

United Nations Framework Convention on Climate Change (2015). United States Intended National Determined Contribution. Recuperado el 1 de junio de 2020 de https://www4.unfccc. int/sites/ndcstaging/PublishedDocuments/United $\% 20$ States $\% 20$ of $\% 20$ America\%20First/U.S.A.\%20First $\% 20$ NDC\%20Submission.pdf

Ungar, S. (1992). "The Rise and (Relative) Decline of Global Warming as a Social Problem”, Sociological Quarterly, vol.33, no 4, pp. 483-501.

Waterman, P.K. (2003), "From Kyoto to ANWR: Critiquing the Bush Administration's Withdrawal from the Kyoto Protocol to the Framework Convention on Climate Change". Transnat'l L. \& Contemp. Probs., vol. 13, pp. 749-769.

Yamin, F. y Depledge, J. (2004). The international climate change regime: a guide to rules, institutions and procedures, Cambridge: Cambridge University Press.

Young, O. (2004). "The consequences of international regimes”, en Underdal, Kirstin and Young, Oran, Regime Consequences, Dordrecht: Springer, pp. 3-23. 